\title{
Contra-paisajes de la globalización: las imágenes-argumento de Mario Bellatín y Manoel de Barros ${ }^{1}$
}

\author{
Contra-paisagens da globalização: as imagens-argumento de Mario \\ Bellatín e Manoel de Barros
}
Counter-landescapes of globalization: images-arguments in Mario Bellatín and Manoel de Barros

Analía Yeruti Galván López e Marcelo Marinho

\begin{abstract}
Resumen
Este estudio desarrolla el análisis de ciertas imágenes que convergen en las obras de Manoel de Barros y Mario Bellatín. En "Materia de poesía" y "Salón de belleza", los autores construyen un contra-paisaje como crítica al proceso de globalización, que articula imágenes someras en las cuales el ser humano poco se espeja. Tendremos como referencia crítica y teórica los escritos de José Santos, César Rendueles, Frédéric Vanderberghe. El análisis se hará con soporte en la imagología (estudio de imágenes), una herramienta interpretativa propia de la literatura comparada. Como resultado, se espera construir una articulación de ciertas imágenes-argumento que se presentarían como una suerte de contra-paisaje ante la globalización que traga y consume a la humanidad en el siglo XXI. Entiéndase por imágenes-argumento a las construcciones verbales que, por medio de los sentidos (visual, auditivo, gustativo, olfativo y tactil), desestabilizan y problematizan los paisajes someros sobre los cuales se sustenta la globalización. Con este trabajo se pretende ver como la poesía puede inducir el lector a un estado de extrañamiento frente a ciertos paisajes globalizados.
\end{abstract}

Palabras-llave: Contra-paisaje, globalización, imágenes-argumento, Manoel de Barros, Mario Bellatín.

\section{Resumo}

Este artigo centra-se na análise de certas imagens que convergem nas obras de Manoel de Barros e de Mario Bellatín. Em "Matéria de poesia" e "Salón de belleza", os autores constroem uma contra-paisagem como crítica ao processo de globalização, que articula imagens ocas nas quais o ser humano pouco se reflete. Teremos como referência crítica e teórica os escritos de José Santos, César Rendueles e Frédéric Vanderberghe. A análise se fará com base na imagologia (estudos de imagens), uma ferramenta interpretativa própria da literatura comparada. Como resultado, busca-se construir uma articulação de certas imagens-argumento que se apresentariam como uma espécie de contra-paisagem frente à globalização que traga e consome a humanidade no século XXI. Entenda-se por imagens-argumento as construções verbais que, por meio dos sentidos (visual, auditivo, gustativo, olfativo e tátil), desestabilizam e problematizam as paisagens ocas sobre os quais se sustenta a globalização. Com esta investigação pretende-se ver como a poesia pode induzir o leitor a um estado de estranhamento frente a certas paisagens globalizadas.

Palavras-chave: Contra-paisagem, globalização, imagem-argumento, Manoel de Barros, Mario Bellatín.

Abstract

This paper is focused on the analysis of certain images that converges into the poetic works of Manoel de Barros and Mario Bellatín. In "Materia de poesía" and "Salón de belleza", the authors build up a counter-landscape as a problematization for the process of globalization, that disseminates hollow images on which the human being could barely mirror himself. We take as a critical and theoretical reference the writings of José Santos, César Rendueles and Frédéric Vanderberghe. The analysis will be done with support on imagology theory (image

1 Artigo apresentado no Simpósio Temático JOVENS PESQUISADORES LATINO-AMERICANOS, durante o II Seminário Latino-Americano de Estudos em Cultura - SEMLACult, em Foz do Iguaçu/PR, Brasil, 2018.

2 Analía Galván es graduanda en Letras y becaria PIBIC-CNPq (Universidad Federal de la Integración Latino-Americana, Foz do Iguaçu/Pr, Brasil, e-mail lgalvananalia@gmail.com), mientras Marcelo Marinho es doctor em Literatura Comparada y Profesor Adjunto de Poéticas Latino-Americanas (Universidad Federal de la Integración LatinoAmericana, e-mail biografia@gmail.com) 
studies), an comparative literature interpretative tool. As a result, we expect to offer an articulation for the images-argument that would present themselves as a kind of counter-landscape in front of the globalization process that engulfs and consumes humankind at the 21 st century. An "image-argument" is understood as a verbal construction that, through the human senses (visual, auditory, gustatory, olfactory and tactile), destabilizes and problematizes the hollow landscapes on which the globalization is sustained. This work is aimed to see how a poetic work piece can bring forth strangeness to the reader, as far as globalized landscapes are concerned.

Key words: counter-landscape, globalization, images-argument, Manoel de Barros, Mario Bellatín.

\section{Introducción}

Para empezar nuestra lectura, tomemos estes conceptos de paisaje propuestos por Federico Italiano: "namely the aesthetical organization of a homogeneous segment of nature, a uniform portion of the world, according to the projection of the perceiving subject" o una "semantic fixation of an experienced portion of the world" (ITALIANO, 2008, s.p.). Es importante recordar que este vocablo y su concepto tienen sus orígenes en el marco de la pintura holandesa del Siglo XVI, es decir, tiene relación cerrada con la ideología y la expansión de la burguesía industrial, mercante y bancaria.

Desde una mirada sociológica, Jorge Barbosa explica que a "paisagem é, portanto, uma marca que exprime um significante (simbólico) e, ao mesmo tempo, é também uma matriz de significados (experiências de tempo e espaço), porque representa a expressão de uma 'razão de existir' da sociedade" (BARBOSA, 2010, s.p.).

Partiendo del supuesto de que el paisaje es una "porción del mundo" y que el paisaje representa "una razón de existir de la sociedad", intentaremos comprender cuales son los argumentos justificativos y convalidativos que la globalización erige en presunta ley social por medio del paisaje.

En esa perspectiva, Miguel Rojas Mix (2006) desenvuelve el concepto de "imagenargumento" y defiende la idea de que las imágenes portan un discurso implícito que influye de manera determinante en las relaciones sociales, culturales, políticas, etc. Por lo tanto, José Santos habla de un mundo "atrapado en imágenes" y concluye que ese es “(...) un mundo altamente tecnificado y economizado en el que impera la ideología tecnológica y utilitarista, estando las relaciones entre los seres humanos cada vez más mercantilizadas" (SANTOS, 2107, p. 23). Así, este trabajo es una tentativa de interpretar las imágenes-argumento en que se convirtieron los paisajes difundidos por medio de la fotografía, del cine, de la televisión, las propagandas, los afiches, los paneles callejeros, pero también por medio de la palabra. En ese contexto, el sociólogo Cesar Rendueles afirma:

La creciente sentimentalización de las relaciones mercantiles y el modo en que las emociones personales y familiares están atravesadas cada vez más por estrategias de gestión de inspiración económica, donde los sentimientos íntimos son objetos de proyecto de maximización y optimización (RENDUELES, 2017, p. 85). 
Con respecto a las relaciones humanas utilitaristas y mercantilizadas en el marco de la globalización, Frédéric Vandenberghe (2014, p. 298) sostiene que, en dentro del sistema, existen además varios elementos constitutivos que favorecen a la mas completa individualización fragmentadora de la sociedad - la competitividad sin límites sería el principal de esos elemento. Para ese sociólogo, “a cultura global é ambígua: envolve a difusão universal dos produtos culturais do capitalismo e a extensão da ideologia consumista assim como, não obstante, contem em si a interpelação local na interpretação daqueles produtos culturais globais" (VANDENBERGHE, 2014, p. 279). En un planeta con más de siete billones de humanos, la competitividad extrema y la cruel competencia por recursos y espacios solo pueden llevar los espacios de vida a lo que hay de más des-humano o profundamente inhumano.

Tal cultura global "es ambigua", como sostiene Vandenberghe, mientras los productos globales mercantilizados (culturales o manufacturados) imponen a los individuos nuevas concepciones de lo local, las cuales alejan al sujeto de su entorno inmediato. El mundo globalizado y enfocado en el consumismo acarrea consecuencias sociales desastrosas: la despersonalización de los espacios, la individualización introspectiva, el deterioro de las relaciones sociales e interpersonales, la competitividad inhumana, la reificación de les seres humanos e demás seres vivos etc. Todo conlleva a un desinterés por el otro, por el encuentro con el otro, por los trueques materiales o simbólicos con la comunidad. Nos encontramos en una sociedad individualizada y egocéntrica, nos ponemos muchas veces incapaces de experimentar la empatía o la alteridad. José Santos propone la idea de que esa sociedad es articulada por

\footnotetext{
"Unas imágenes sin imaginación (sin verdadera profundidad) que han fragmentado toda una cultura de lo visual convertida en instrumento de socialización. La transmisión del conocimiento ha pasado de ser escrita a ser visual, de lo teórico a lo práctico, donde lo verdaderamente útil es ganar dinero" (SANTOS, 2107, p. 23).
}

Las imágenes huecas y someras propuestas por el mundo globalizado son imágenes que imponen nuevas formas huecas y someras de socializar, de tratar la realidad, de comprender la sociedad: tales son las "imágenes sin imaginación" de que habla Santos. Esas son las imágenes-argumento que sostienen el avance de la globalización, pues, si el diccionario DEM define la palabra "argumento" como "razonamiento que se dá para defender o combatir una opinión, una idea, una propuesta, etc", podemos decir que las imágenes 
mediáticas y sobretodo los paisajes triunfales conllevan una propuesta de justificativa para el proceso mismo de esparcimiento y consolidación de la ideología burguesa en escala global.

Así, el proceso de globalización sumerge al individuo bajo un océano de "imágenesargumento" por medio de las cuales consolida diversas formas de comportamiento. El consumismo y el individualismo dan forma al imaginario (colectivo de imágenes) que se presenta como la clave para alcanzar la plenitud. Diseminase "imágenes-argumento" sin imaginación que imprimen y autentican formas de relacionamiento entre los individuos y la sociedad.

En contrapartida, Roberto Corrêa (2011) afirma que el arte se ocupa de imponer un orden al caos de la experiencia humana, razón por la cual el análisis de las producciones estéticas contribuye a la comprensión de las relaciones interpersonales e intrasociales. Por tales razones, intentaremos analizar las imágenes-argumento que proponen Mario Bellatín y Manoel de Barros en sus obras poéticas, las cuales parecen proponerse como contra-paisajes con relación al orden hegemónico de la sociedad.

\title{
I. Barros y Bellatín: panorama crítico.
}

Manoel de Barros (Brasil 1916-2014) y Mario Bellatín (México, 1960), en su producción literaria, crean imágenes que se contraponen y se complementan en el ámbito del imaginario latinoamericano. Sus imágenes poéticas conducen al lector a una zona de preguntas sin respuestas, dentro de las cuales se inicia la búsqueda de significados para conceptos y situaciones que determinan la existencia humana. Estos autores a través de imágenes que en principio están privadas de sentido lógico, conducen al lector a un universo absurdo, paradojal y en las rayas de lo indecible.

En ese contexto, con respecto a la obra de Mario Bellatín, Lulú Rubio afirma:

\begin{abstract}
El tiempo de la vanidad y la fantasía del salón de belleza, etéreo e impalpable, fue intercambiado en el Moridero por el tiempo de la agonía: un tiempo presente, donde no hay un antes o un después, es un solo tiempo largo, desesperadamente eterno. Asimismo, al final de la novela aumenta la tensión narrativa dentro de una estructura circular, ya que la historia inicia y sugiere terminar en un mismo punto, en el salón de belleza. Lo mismo sucede en los acuarios: se regresa a las mismas especies del principio, quizá dentro de una idea de eterno retorno, que hace presentir un tiempo aún más angustiante. Sin embargo, es aquí donde también se está proponiendo la alternativa, temporal, a la agonía, se está haciendo alusión al ciclo vida - muerte vida. (RUBIO, 2009, s.p.)
\end{abstract}

Esa estructura circular es un detalle sumamente importante que se ve en el cuento "Salón de Belleza", en el cual la articulación de menciones laberínticas, personajes sin nombre, espacios sin indicación geográfica y repetición monótona de actividades es una 
referencia al golpeo monótono y constante que la globalización imprime a la vida humana en general - que se ve atrapada en actividades sin sentido, en un tempo circular, tal como les peces en el acuario que abren esa alegoría poética sobre el tema de las enfermedades sin cura del mundo productivo y competitivo, en el cual la circulación y el consumo de mercancías reglan el ritmo de la existencia de todos los seres (a empezar por los peces, coisificados y mercantilizados, imagen metafórica para los individuos de la especie humana).

Por otro lado, María Heloísa Días, al hablar de Manoel de Barros, afirma:

"Tornar a palavra uma coisa manipulável como um brinquedo e transformar as coisas existentes numa linguagem desconcertante se interpenetram no espaço da poesia. Assim, tanto em relação à língua enquanto instrumento do poético quanto em relação à realidade social retratada, o intuito é o mesmo: virar do avesso as convenções, criar o despropósito" (DIAS, 2009, p.129).

El "linguagem desconcertante" que utiliza Barros se ofrece como una ventana abierta sobre la anestesia existencial en la que se mueven los seres coisificados y mercantilizados en les espacios huecos y someros del planeta globalizado. En ese sentido, João Carrascoza afirma: "Ao se afastar dos grandes temas, ou melhor, abordá-los por meio das miudezas, Manoel de Barros nos entrega uma obra poética de costas para a hegemonia corrente" (CARRASCOZA, 2018, p.15). Tal afirmación, como se ve, también es válida para Bellatín. Ambos producen una creación literaria de espaldas a la hegemonía, proponen una visión distinta del mundo por medio del paisaje que crean y presentan a sus lectores: sus imágenes pueden ser entendidas como contra-paisajes, en contrapunto a los paisajes triunfales difundidos por los agentes de la globalización.

\section{Contra-paisajes e imágenes-argumento en Barros y Bellatín.}

Cuales son las posibles relaciones entre los paisajes propuestos por Bellatín y Barros en sus producciones literarias? Para intentar llegar a elementos de respuesta, empecemos con este trecho de "Salón de Belleza", de Bellatín: "Ya casi no individualizo a los huéspedes. He llegado a un estado tal en el que todos son iguales para mí. Al principio los reconocía. Incluso una que otra vez llegué a encariñarme con alguno. Pero ahora no son más que cuerpos en trance hacia la desaparición." (BELLATÍN,1996, p.21).

En ese pasaje, el protagonista-narrador (un peluquero que transforma su "salón de belleza" en un "moridero" que recibe y alberga enfermos sin esperanza de cura), Bellatín parte de un recorte imaginario de pago (paisaje, landschaft) para presentar a sus lectores el universo de los ninguneados - para aquí retomar el concepto propuesto por Octavio Paz. 
Enfermos, transgéneros, trabajadores manuales, ancianos - todos sin nombre: meros cuerpos invisibilizados y despersonalizados, reducidos a cosas que aguardan el descarte final. El peluquero sin nombre se dedica a mantener en vida a los enfermos terminales que llegan a su puerta en busca de atención y supervivencia. Él se dedica a ejecutar todos los días un cronograma de actividades basado en el equilibrio de la alimentación, el abrigo y el aseo adecuado - y realiza esa tarea de forma mecánica y monótona. Para inducir la supervivencia de estos vivos-muertos, el peluquero no se permite tener un imprevisto, lo tiene todo perfectamente calculado. Aquí se ve al individuo humano cosificado por la globalización, una masa anónima de cuerpos que suele llevar una existencia vegetativa tan solo para garantizar la ganancia de unos puñados de cobre a sus cuidadores y explotadores - personal médico y farmacéutico, fabricantes de productos diversos, comerciantes, agentes públicos, prestadores de servicios y, por fin, los agentes fúnebres y religiosos: cosas sin nombre, reducidas a su función en el paisaje social. Ese indivíduo globalizado se define y se mide con criterios de maximización y eficiencia, mientras el paisaje poético contesta la visión económica y utilitarista que pasa a lo largo de la felicidad, del amor o del dolor - huellas humanas que no se ve en los paisajes triunfales de la globalización. Esa es una persona insensible ante el dolor y el drama humano, es individualista y egocéntrica, ajena a la empatía y al Otro.

Por su lado, Barros también inscribe a los ninguneados en su paisaje poética: "as coisas jogadas fora / tem grande importância / como um homem jogado fora" (BARROS, 2010). Barros alerta sus lectores de los riesgos de la visión masificadora sobre el ser humano: exclusión de los improductivos (llevados a ese punto por los mecanismos de formación y remplazo de trabajadores); descarte de seres humanos cosificados; perecibilidad de la condición humana; desamparo; individualismo; insensibilidad; pérdida de significado para la vida etc. Aquí el argumento propuesto es de que los excluidos son importantes en el mismo grado que los demás. Barros denuncia la utilización de los cuerpos reificados y resalta la dignidad última que todos portamos: somos todos ese "hombre jogado fora". Barros trae al paisaje social una imagen que se contrapone fuertemente con los paisajes triunfales propuestos por la publicidad, vehiculizados por los medios de comunicación, difundidos por la industria cultural, consolidados en el imaginario colectivo por las redes sociales.

El hombre "jogado fora" propuesto por Barros corresponde a los enfermos de Bellatín, imagen-argumento en la cual se evidencia esta mirada acusativa sobre el consumismo, el éxito personal, la diversión superflua - en una sociedad hueca y somera.

Esas ideas convergen con otra imagen-argumento que encontrase en Bellatín: 
“A nivel económico nunca fue más floreciente que cuando el salón de belleza se convirtió en un Moridero. Entre las donaciones, las herencias de los fallecidos y los aportes de los familiares logré reunir un buen capital. Así que por ese lado no tendré problemas para llevar a cabo los cambios que quiero realizar" (BELLATIN, 1996, p. 21).

En ese pasaje, se ve al peluquero convertirse muy temprano en explotador económico del dolor y del sufrimiento ajeno. La ideología burguesa globalizada transforma en goce colectivo la imagen del suceso económico personal: el proyecto de adquirir bienes y productos se asienta en el imaginario colectivo como un fin en si propio e como una justificativa para la existencia. El individuo globalizado ve al trabajo como un medio para alcanzar sus metas personales, para espejarse en las “imágenes sin imaginación” de que trata Santos. El paisaje descrito por Bellatín es un paisaje en el que las relaciones entre los hombres se suceden desde una perspectiva industrial y despersonalizada, la cual está enfocada en la búsqueda del beneficio propio. Por otro lado, el pasaje también remite a la práctica corriente de pagarse a uno para que se ocupe de personas que ya no tienen utilidad en el seno de la familia, es decir, las personas que se transforman en fardo a los familiares y que, como en el poema de Barros, deben se transformar en un "homem jogado fora".

\section{Consideraciones finales}

Mediante este análisis, observamos que Bellatín y Barros se dedican a presentar a sus lectores ciertos modos alienados y huecos de vivir la existencia humana. Bellatín abre la pregunta a través del vacío de las actividades que evidencia el peluquero en toda la obra y Barros abre la pregunta a través de la inclusión, a lo largo de su poesía, de los seres invisibilizados y de otros seres que escapan a la función perecible que les reserva una sociedad humana intensamente utilitarista. Las obras se proponen a despertar al lector a través del paisaje contra-hegemónico plasmado en sus páginas, en el sentido de fomentar la búsqueda de respuestas que transciendan al nihilismo. Ambos autores denuncian el "capitalismo canalla" (Rendueles) globalizado, por medio de un contra-paisaje que se contrapone a esos paisajes triunfales que intentan justificar la expansión del "moridero" en el que la globalización transforma rápidamente nuestro planeta.

\section{Referencias}

BARBOSA, Jorge Luiz. Paisagens da natureza, lugares da sociedade: a construção imaginária do Rio de Janeiro como cidade maravilhosa. Revista bibliografica de geografia y ciencias 
sociales, Barcelona, v. XV, n. 865, 2010. ISSN: 1138-9796. Disponible en: http://www.ub.edu/geocrit/bw-15.htm Acceso en: 20 abril de 2018.

BARROS, Manoel de. Poesia Completa. São Paulo: Leya, 2010.

BELLATÍN, Mario. Salón de Belleza y El Efecto invernadero. México DF: Consejo Nacional para la Cultura y las Artes/Ediciones del Equilibrista, 1996.

CARRASCOZA, João Anzanello. O consumo, o estilo e o precário na poesia de Manoel de Barros. Bakhtiniana, Rev. Estud. Discurso, São Paulo, v. 13, n. 1, p. 5-16, Apr. 2018. ISSN 2176473. Disponible en: http://www.scielo.br/scielo.php?script=sci_arttext\&pid=S217645732018000100005\&lng=en\&nrm=iso Acceso en: 06 Jun, 2018.

CORRÊA, Roberto Lobato. As pequenas cidades na confluência do urbano e do rural. S/D. Organização do espaço: Dimensões, processos, forma e significado. GEOGRAFIA, Rio Claro, v. 36, Número Especial, p. 7-16, set. 2011. Disponible en: http://www.revistas.usp.br/geousp/article/view/74228. Acceso en: 20 de abril de 2018

DIAS, Maria Heloísa. Espaço e linguagem na poesía de Manoel de Barros: uma constante (des) aprendizagem. Antares. n. 1, p. 125-133, jan. 2009. Disponible en: http://www.ucs.br/etc/revistas/index.php/antares/article/viewFile/304/264. Acceso en: 25 de junio de 2018.

ITALIANO, Federico. Defining Geopoetics. TRANS-, v. 6. p. 1-11, 2008. Disponible en: http://journals.openedition.org/trans/299. Acceso en: 18 abril 2018

RENDUELES, César. La gobernanza emocional en el capitalismo avanzado. Entre el nihilismo emotivista y el neocomunitarismo adaptativo. Rev.estud.soc, Bogotá, n. 62, p. 82-88, Oct. 2017. ISSN 0123-885X. Disponible en: http://www.scielo.org.co/scielo.php?script=sci_arttext\&pid=S0123-885X2017000400082 Acceso en:18 Apr. 2018.

RUBIO, Lulú. De la vanidad a la agonía: el grotesco de Bajtín en Salón de belleza de Mario Bellatin. Espéculo. Volúmen XIV, Número 40, noviembre 2008 - febrero 2009. Available from: http://pendientedemigracion.ucm.es/info/especulo/numero40/salonbe.html Access on 18 Apr. 2019.

ROJAS MIX, Miguel. El imaginario: civilización y cultura del siglo XXI. Buenos Aires: Prometeo Libros, 2006.

SANTOS, José Antonio. El hombre tecnológico como fetiche de la modernidad ampliada. Acuerdos y desacuerdos con la posmodernidad como resistencia, de Jesús Ballesteros. Díkaion, Chia.v. 26, n. 1, p. 11-30, Jan. 2017. ISSN 0120-8942 Disponible en: 
http://www.scielo.org.co/scielo.php?script=sci_arttext\&pid=S0120-

89422017000100011\&lng=en\&nrm=iso Acceso en: 18 Apr. 2018

VANDENBERGHE, Frédéric. Globalização e individualização na modernidade tardia. Uma introdução teórica à sociologia da juventude. Mediaçoes, Londrina, v.19, n.1, p. 265-316, 2014. Disponible en: http://www.uel.br/revistas/uel/index.php/mediacoes. Acceso en: 17 de abril de 2018. 